\title{
Properties Evolution of Ion-plasma Coatings on the Base of Transition Metal Nitrides
}

\author{
P.V. Turbin, V.M. Beresnev, D.V. Horokh \\ V.N. Karazin Kharkiv National University, 4, Svobody Sq., 61022 Kharkiv, Ukraine
}

(Received 21 August 2020; revised manuscript received 15 October 2020; published online 25 October 2020)

\begin{abstract}
Some regularities of formation of coatings on the basis of nitrides of transition metals obtained by vacuum-arc method are determined. The coatings were formed using RF pulse stimulation of the substrate. In order to eliminate the droplet fraction, ion-plasma flow separation was used. To determine the physical and mechanical properties of the coatings, scanning electron microscopy and the nanoindentation method were used. The surface morphology of the coatings was analyzed using an electron-ion microscope. The evolution of physical and mechanical properties of the coatings was determined by the physical parameters of deposition. The composition of the sprayed cathodes, reaction gas pressure, the displacement potential applied to the substrate determine the structural and phase state of the obtained coatings and, thus, their physical and technical characteristics. The use of silicon as an alloying element allows to form an intercrystalline layer of $\mathrm{Si}_{3} \mathrm{~N}_{4}$. Segregation of amorphous or quasiamorphic matter in the intercrystalline space determines the composite structure of the coating. Composite coatings are characterized by more advanced physical and mechanical properties. The nanocomposite coatings obtained in the work reach the state of superhard coatings $(53 \mathrm{GPa})$ and high values of the modulus of elasticity (430 GPa). Under certain conditions, the formation of the coating acquires a textured state. The degree of change in the size of the coherent scattering regions from the deposition conditions is analyzed. It is established that the optimal control of the physical parameters of deposition allows to form ion-plasma protective coatings with programmable properties.
\end{abstract}

Keywords: Vacuum-arc sputtering method, Physical parameters of coating formation, Physical and technical properties of coatings.

DOI: 10.21272/jnep.12(5).05031

PACS numbers: 81.07.Bc, 61.05.cp,68.55.jm, 61.82.Rx

\section{INTRODUCTION}

The paper discusses the physical features of the creation of new materials in the form of coatings based on transition metal nitrides. Such coatings are characterized by improved physical, mechanical and thermal characteristics.

An important property of nitrides is their high hardness. This property is especially significant when using such compounds as wear-resistant coatings. Hardness is a characteristic that reflects the binding energy, structure symmetry and deformation properties. The hardness of compounds is associated with the type and nature of the distribution of interatomic bonds; it grows with an increase in the lattice energy, heat of formation and energy of atomization. A higher value of the interatomic interaction energy corresponds to a higher hardness. Joints with a high modulus of elasticity are characterized by high hardness. This fact is a consequence of the proportionality between the stress required for the movement of dislocations and the modulus of elasticity [1].

Thus, the hardness is determined by the features of the electronic structure [1]. The electronic structure of nitride films directly depends on the physical and technological parameters of the formation of coatings by ion-plasma methods.

The paper examines the regularities of the formation of multi-element coatings in the form of a single-phase solid solution based on transition metal nitrides. The atoms of the alloying elements are embedded in the crystal lattice of the transition metal nitride and, due to the difference in atomic radii, create stresses that prevent deformation. Alloying increases the hardness of the coatings up to $40-50 \mathrm{GPa}$ and shear resistance.

The formation of composite (multiphase) coatings is based on thermodynamic phase separation, which ensures the formation of a stable structure. Phase separation is achieved during the coating process at sufficiently high nitrogen concentrations and activities. Nitrogen provides high thermodynamic driving forces. The temperature of the substrate provides diffusioncontrolled phase segregation so that the segregation process can take place quickly enough during application. Maximum hardness can be achieved, for example, when a monolayer of a covalent nitride such as $\mathrm{Si}_{3} \mathrm{~N}_{4}$ or $\mathrm{BN}$ covers the surface of a polar solid transition metal nitride nanocrystallite.

This work is devoted to the study of the physical principles of the formation of coatings obtained by the vacuum-arc method, based on transition metal nitrides, in order to determine the possibilities of controlling the processes of coating formation and achieving programmable properties.

\section{MATERIALS AND METHODS OF RESEARCH}

The coatings under study were formed by vacuum arc deposition.

The coatings were applied by spraying $\mathrm{Ti}+\mathrm{Zr}+\mathrm{Si}$, $\mathrm{Ti}+\mathrm{Hf}+\mathrm{Si}, \quad \mathrm{Ti}+\mathrm{Zr}+\mathrm{Nb}$ solid cathodes onto $12 \mathrm{Kh} 18 \mathrm{~N} 10 \mathrm{~T}$ stainless steel, steel 3 , and steel 45 in a nitrogen atmosphere.

The substrate temperature exceeded $500{ }^{\circ} \mathrm{C}$.

The bias potential was applied to the substrate from an $\mathrm{RF}$ generator, which generated pulses of damped oscillations with a frequency of $<1 \mathrm{MHz}$. The duration of each impulse was $60 \mathrm{~ms}$ with a repetition rate of $10 \mathrm{kHz}$. The magnitude of the negative self-bias of the potential on the substrate, due to the RF diode effect, was $2 \mathrm{kV}$ at the beginning of the pulse and decreased at the end of the pulse. 
The structure of the coatings was investigated by means of transmission electron microscopy. The morphology of the coating surface was determined by a Quanta 200 3D electron-ion scanning microscope equipped with an EDAX X-ray fluorescence microanalyzer with software and an automated SURTRONIC 25 precision contact profilometer.

The study of the mechanical characteristics of the coatings was carried out by the nanoindentation method on a Nanoindenter G200 device (MES Systems, USA).

Tribological tests were carried out on an automated friction machine "Tribometer", CSM Instruments in air according to the "ball-disk" scheme at a temperature of $20^{\circ} \mathrm{C}$. A $6 \mathrm{~mm}$ diameter ball made of certified sintered material $\mathrm{Al}_{2} \mathrm{O}_{3}$ was used as a counterbody. The disks on which the coatings were applied were made of steel 45 $(\mathrm{HRC}=55)$ with a diameter of $50 \mathrm{~mm}$ and a thickness of $5 \mathrm{~mm}$. The load was $3.0 \mathrm{~N}$, the sliding speed was $10 \mathrm{~m} / \mathrm{s}$.

\section{ANALYSIS OF RESEARCH RESULTS}

The physical factors that make it possible to control the properties of the formed ion-plasma coatings are: the pressure of the reaction gas in the vacuum chamber, the constant or pulsed bias potential applied to the substrate, the composition of the sputtered cathode, and the percentage of the alloying element. Silicon, boron, aluminum, niobium, etc. are used as alloying elements.

The study of the regularities of the influence of physical parameters of deposition on the quality of coatings is carried out by comparing the physical and mechanical characteristics of protective coatings based on (Ti, Al)N, (Ti, Cr)N, (Ti, Zr)N, (Ti, Hf)N solid solutions and coatings obtained by alloying solid solutions with silicon and niobium.

In [2], protective coatings based on the (Ti-Al-Si)N system were deposited by the vacuum-arc method. It was found that as the nitrogen pressure in the deposition chamber increased, a transition was observed from the nanocrystalline state $\left(P_{N}<0.04 \mathrm{~Pa}\right)$ to the nanocomposite $\left(P_{N}=0.04-0.66 \mathrm{~Pa}\right)$ and to the amorphous $\left(P_{N}=0.66-1.1 \mathrm{~Pa}\right)$ states. The highest mechanical characteristics and thermal stability were found in coatings with a nanocrystalline structure and in nanocomposite coatings with a low amorphous phase content. The hardness of the coatings of the (Ti-Al-Si)N system reached $47 \mathrm{GPa}$.

In [3], films of the (Ti-Si)N, (Zr-Si)N, (Ti-Al-V-Si)N, and (Ti-Al-Si)N systems were synthesized by vacuumarc method in a gaseous nitrogen. The amount of silicon in the films varied from 0 to 19 at. \%. With an increase in the silicon content, an increase in the hardness of the (Ti-Si)N, (Ti-Al-V-Si)N and (Zr-Si)N films was found. The maximum recorded hardness is $42 \mathrm{GPa}$.

Silicon is an amorphous element, therefore, for example, in the sequence $\mathrm{TiN} \rightarrow \mathrm{TiN}+\mathrm{a}-\mathrm{Si}: \mathrm{N} \rightarrow \mathrm{a}-(\mathrm{Si}, \mathrm{Ti}) \mathrm{N}$ phases with silicon are mainly amorphous [4]. For example, it was shown in [5] that the addition of Ti atoms to a-Si:N films revealed that the films remain amorphous up to 15 at. \% Ti (i.e., the a-( $\mathrm{Si}, \mathrm{Ti}) \mathrm{N}$ phase is formed). Upon reaching 15 at. \% $\mathrm{Ti}$, the $\mathrm{TiN}$ phase is formed inside the amorphous matrix. At a higher $\mathrm{Ti}$ content, crystalline TiN nanocolumns are formed inside the amorphous matrix. The solubility of the crystalline component in the amorphous component plays an important role in the process of phase formation. For example, high solubility reduces the biphasic region to a smaller composition range.

The use of the direct-flow regime of the plasma flow in the vacuum-arc deposition of coatings of the (Ti-Hf$\mathrm{Si}) \mathrm{N}$ system leads to the formation of a non-textured polycrystalline coating. The coating is characterized by a significant content in the (Ti, Hf)N solid solution of element Hf, the atoms of which have a higher scattering power in comparison with Ti atoms [6].

When separating the plasma beam, the synthesized coatings of the (Ti-Hf-Si) N system are characterized by a different degree of texture. With an increase in the bias potential voltage to $-200 \mathrm{~V}$ and the use of a scheme with separation during deposition, coatings with a smaller average crystallite size (up to $5 \mathrm{~nm}$ ) are formed and the fraction of textured crystallites (less than 20 vol. \%) is significantly reduced. In this case, the texture axis has the [001] orientation.

Fig. 1 shows the dependences of the crystallite sizes of the coatings of the (Ti-Zr-Si)N and (Ti-Hf-Si)N systems on the reaction gas pressure $P$ and the bias potential $U$. The use of annealing significantly affects the crystallite sizes and leads to their increase.

It follows from the research results that an increase in the bias voltage from $U=-100 \mathrm{~V}$ to $U=-200 \mathrm{~V}$ (i.e., an increase in the energy of the plasma flow) leads to an increase in the texture of the fractions and the formation of a lattice with the same value of the spatial period.

Analysis of the data of X-ray diffraction studies [6-8] indicates the characteristic structural features of coatings formed from targets of identical composition. The properties of the coatings differ greatly depending on the separation application, pressure of the reaction gas and magnitude of the displacement potential.

The reason for this phenomenon may be the inhomogeneity of the distribution of hafnium atoms in the coating, with their predominant content in the lattice sites of textured crystallites. In this case, the formation of a texture leads to an increase in the average crystallite size in the direction of incidence of the atoms forming the coating, that is, perpendicular to the plane of the growing surface. The above results refer to samples obtained at a nitrogen pressure of $0.6-0.7 \mathrm{~Pa}$ in a working chamber during application. In the case of a decrease in the nitrogen pressure to $0.3 \mathrm{~Pa}$ carried out for a mode with separation at a bias potential voltage of $-200 \mathrm{~V}$, an increase in the relative content of heavy Hf atoms in the coating occurs. In addition, as the pressure of the reaction gas decreases, the average crystallite size decreases [7].

In the formation of ion-plasma (Ti-Hf-Si) N coatings, the determining factor is the separation of the ionplasma flow, which results in a decrease in the concentration of $\mathrm{Hf}$ atoms in the coating.

An increase in the bias potential applied to the substrate during deposition by selective removal of light atoms stimulates the enrichment of the coating with $\mathrm{Hf}$ atoms. When a coating is deposited with segregation, there is an axial structuring of predominant crystal growth $[4,5,7]$. 


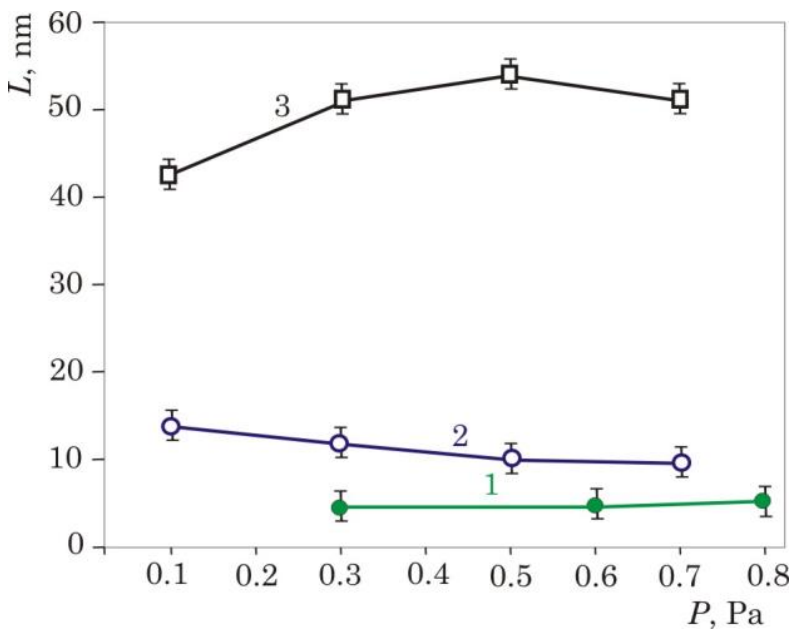

Fig. 1 - Dependence of the crystallite size of the coating on the nitrogen pressure: 1 - coatings of the (Ti-Hf-Si)N system obtained at $U=-200 \mathrm{~V} ; 2$ - coatings of the (Ti-Zr-Si)N system obtained at $U=-200 \mathrm{~V} ; 3$ - coatings of the (Ti-Zr-Si)N system obtained at a bias potential $U=-200 \mathrm{~V}$ after annealing at a temperature of $1273 \mathrm{~K}$

In films deposited without segregation, no texture is observed. The conditions for the formation of nanocomposite (Ti-Hf-Si)N coatings lead to significant deformation of the crystal lattice, which determines the development of compressive stresses in the coating.

Fragments of X-ray photographs illustrate the determination of the crystal lattice deformation of the (Ti-Hf-Si)N coating with separation by superimposing lines under oblique shooting conditions: for the sample $(U=-100 \mathrm{~V})$ a deformation of $-1.9 \%$ is observed (the lattice parameter $a=0.4305 \mathrm{~nm}$ ), and $-1.6 \%$ for the sample (bias potential of $-200 \mathrm{~V}, a=0.4303 \mathrm{~nm}$ ) [6-8].

Fig. 2 and Fig. 3 show graphs characterizing the dependence of the hardness and elastic modulus of the coatings on the nitrogen pressure and the values of the accelerating voltage applied to the substrate.

It follows from the graphs that increasing the nitrogen pressure to a certain value improves the mechanical characteristics of the coatings. An increase in the hardness and modulus of elasticity of the formed coatings is observed.

In the process of research, the optimal values of the bias potential applied to the substrate are determined. The bias potential value of $-200 \mathrm{~V}$ for most of the coatings considered in the work corresponds to the maximum values of hardness and elastic modulus.

For the curves of the graphs in Fig. 2 and Fig. 3, the maximum values of the mechanical characteristics $H$ and $E$ of the coatings are characteristic. The maxima are presumably caused by the approach of the chemical composition of the formed coatings to the stoichiometric composition under the conditions of certain deposition parameters. A further increase, for example, in the pressure of the reaction gas leads to a supersaturation with nitrogen. An increase in the bias potential leads to increased radiation exposure, which negatively affects the quality characteristics of the coating.

For nitrides of transition metals, the formation of interstitial phases by them is characteristic [6]. The introduction phases of the stoichiometric composition have relatively simple crystal lattices based on typical metal packings. Interstitial atoms are located in the interatomic spaces of the lattice. Interstitial solid solutions at certain compositions are capable of ordering with decreasing temperature.

An important difference between refractory compounds, built according to the type of interstitial phases, is the ability to form defect structures with a lack of non-metal atoms in the lattice. Defectiveness of the structure to a large extent affects their properties. Ideal stoichiometry is usually not observed in these phases; deviations from stoichiometry are more typical for them $[4,6]$. With the formation of such defect structures, up to a certain content of non-metal, the structure remains unchanged, only the parameter of the corresponding crystal lattice changes, as well as the physical properties. Below this non-metal content, the lattice is rearranged.

Thus, metal-like refractory compounds constructed according to the type of interstitial phases have certain regions of homogeneity. These areas are narrowed with increasing number of the group of their constituent metals $[5,7]$.

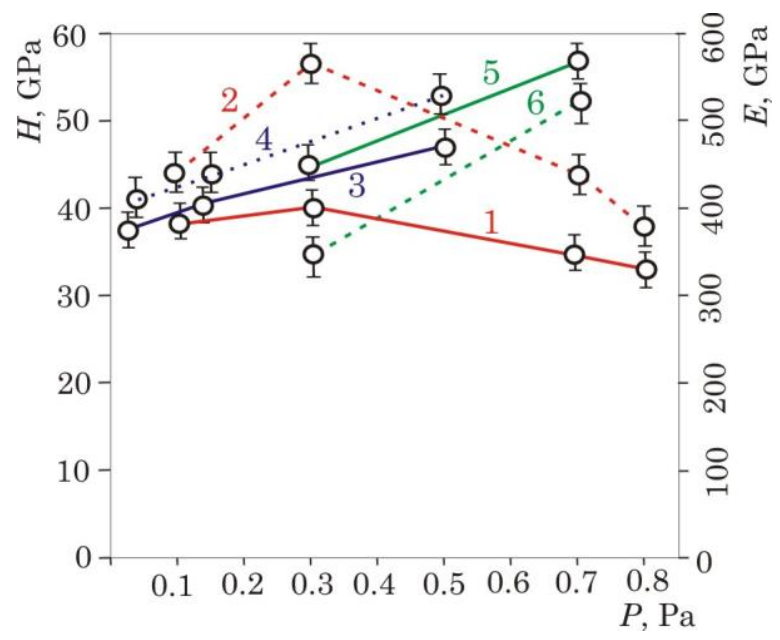

Fig. 2 - Dependence of hardness $H$ and elastic modulus $E$ on nitrogen pressure for coatings based on the systems: (Ti-Zr-Si)N ( $H$-line 1, $E$-line 2$)$; (Ti-Zr-Nb)N ( $H$ - line 3 , $E$ - line 4); (Ti-Hf-Si)N ( $H$ - line $5, E$ - line 6$)$

The unit cell volume of the interstitial solid solution at a low concentration of the metalloid increases with an increase in the latter. This effect is quite natural, since the diameter of the metalloid atom is larger than the diameter of the sphere inscribed in the corresponding interatomic gap of the metal sublattice. However, at high concentrations of non-metal, the dependences of the lattice periods on the concentration of non-metal are different.

While the lattice periods of titanium nitrides increase upon saturation with nitrogen up to the composition MeN, inverse dependences are observed for zirconium and hafnium nitrides. The largest values of the periods of $\mathrm{ZrN}_{x}$ and $\mathrm{HfN}_{x}$ correspond to the phases with minimum nitrogen content; with an increase in nitrogen content, the period decreases.

Apparently, there are two possible reasons for the decrease in the lattice period with an increase in the 
concentration of the metalloid. First, it is the defectiveness of the metal sublattice. Second, the peculiarity of the electronic structure of the phase and the increase in the bond forces in the lattice caused by these features with an increase in the concentration of the metalloid near the stoichiometric composition, leading to the compression of the lattice $[4,5]$.

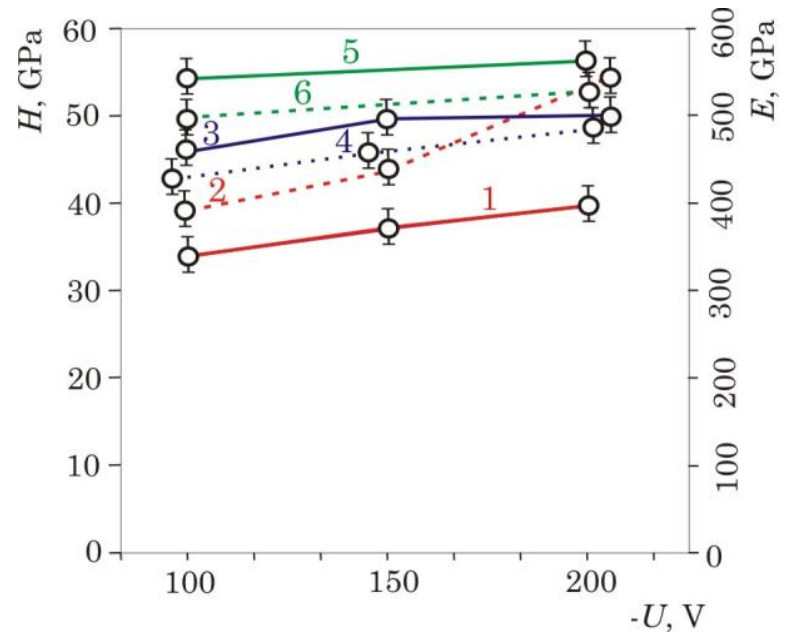

Fig. 3 - Dependence of hardness $H$ and elastic modulus $E$ on the displacement potential for coatings based on systems: (Ti-Zr-Si)N ( $H$ - line 1, $E$ - line 2); (Ti-Zr-Nb)N ( $H$ - line 3 , $E$ - line 4); (Ti-Hf-Si)N ( $H$ - line 5, $E$ - line 6)

The temperature effect on the ion-plasma coatings obtained in the course of research significantly affects their properties. A change in the structural-phase state is observed. The sizes of the coherent scattering regions change. In our case, an increase in the crystallite size was observed upon annealing of the initial coatings. Annealing enhances the segregation of the intercrystalline amorphous substance.

The optimal combination of the composition of the sputtered cathodes, nitrogen pressure and accelerating bias potential made it possible to achieve the following indicators of the mechanical characteristics of the studied coatings: (Ti-Zr-Si)N $-H=48 \mathrm{GPa}, E=425 \mathrm{GPa}$; (Ti-Zr-Nb)N $-H=44$ GPa, $E=398$ GPa; (Ti-Hf-Si)N $H=53 \mathrm{GPa}, E=430 \mathrm{GPa}$.

Tribological studies have shown that the use of silicon as an alloying element contributed to a significant decrease in the coefficient of friction of the investigated coatings.

The values of the friction coefficient $\mu$ and wear resistance obtained during the tests "(Ti, Hf)N coating $\mathrm{Al}_{2} \mathrm{O}_{3}$ " and "(Ti-Hf-Si)N coating $-\mathrm{Al}_{2} \mathrm{O}_{3}$ " are shown in Fig. 4a and Fig. 4b, respectively. The study of the frictional properties of coatings indicates that the coefficient of friction of (Ti-Hf-Si) N coatings is 3.5 times lower than for coatings based on (Ti, Hf)N. This fact is determined by the structural-phase composition of the coatings. The composite coating structure (Ti-Hf-Si)N is provided by $\mathrm{Si}$ doping. The mechanical properties of the compared coatings differ significantly. In particular, the hardness of (Ti-Hf-Si)N coatings $H=38-39 \mathrm{GPa}$ and for (Ti, Hf) N coatings $H=29-30 \mathrm{GPa}$.

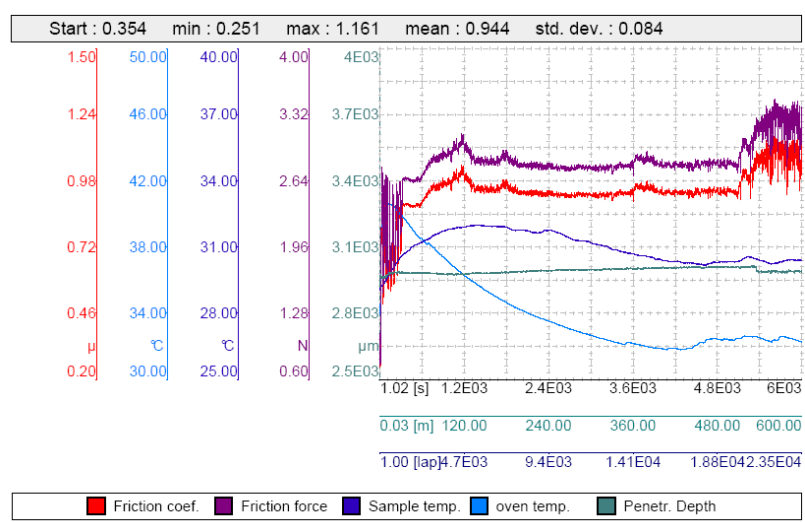

a

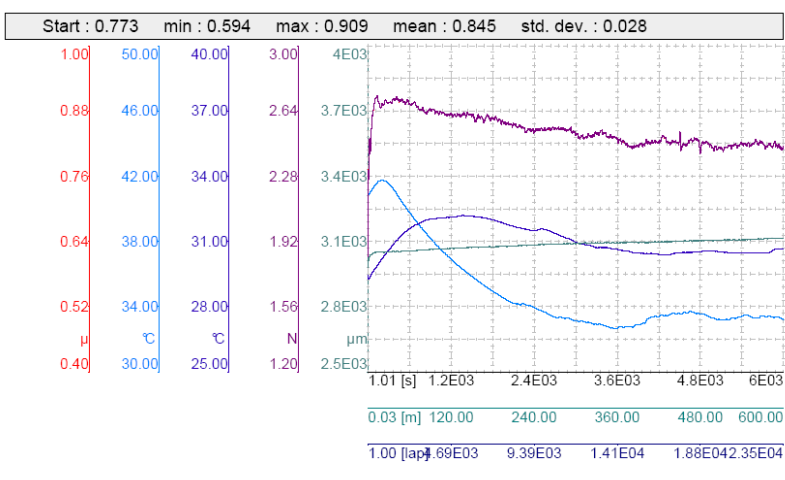

$\square$ Friction coef.

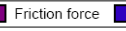

Samperte

Fig. 4 - Results of tribological tests of the following systems: $\mathrm{a}-$ "(Ti, Hf) N coating $-\mathrm{Al}_{2} \mathrm{O}_{3}$ "; $\mathrm{b}-$ "(Ti-Hf-Si) N coating $-\mathrm{Al}_{2} \mathrm{O}_{3}$ "

From the results of tribotechnical tests of coatings based on the (Ti-Hf-Si)N system, it follows that the wear resistance of the coatings increases with an increase in the test temperature from $300^{\circ} \mathrm{C}$ to $500{ }^{\circ} \mathrm{C}$. So, for the system with 40.0 at. \% Ti, 9.0 at. \% Hf, 8.0 at. $\% \mathrm{Si}, 43.0$ at. $\% \mathrm{~N}$, the wear factor of the coating at a temperature of $300^{\circ} \mathrm{C}$ is $2.22 \cdot 10^{-5} \mathrm{~mm}^{3} /(\mathrm{N} \cdot \mathrm{m})$, and at a temperature of $500{ }^{\circ} \mathrm{C}$ it is $1.49 \cdot 10^{-5} \mathrm{~mm}^{3} /(\mathrm{N} \cdot \mathrm{m})$. In this case, the wear factor of the counterbody at these temperatures varies from $3.14 \cdot 10^{-5} \mathrm{~mm}^{3} /(\mathrm{N} \cdot \mathrm{m})\left(300{ }^{\circ} \mathrm{C}\right)$ to $2.81 \cdot 10^{-5} \mathrm{~mm}^{3} /(\mathrm{N} \cdot \mathrm{m})\left(500{ }^{\circ} \mathrm{C}\right)$.

It is known that the process of formation of silicon nitride, depending on the supplied nitrogen, can proceed in two ways. The first way is at a relatively low pressure, when $n_{\mathrm{N}_{2}} / n_{M e} \leq 1$. In this case, as shown in [9, 10], the formation of the $\mathrm{SiN}$ phase with a cubic lattice of the TiN type can occur. At the same time, the amount of free energy is relatively low and amounts to $192 \mathrm{~kJ} / \mathrm{mol}$. The second way is realized at high nitrogen fluxes to the growth surface. In this case, in accordance with the thermodynamic approach based on minimizing the Gibbs free energy, at a sufficiently high nitrogen activity, the reaction $3 \mathrm{SiN}+0.5 \mathrm{~N}_{2}=\mathrm{Si}_{3} \mathrm{~N}_{4}$ can occur, and the energy value is $168 \mathrm{~kJ} / \mathrm{mol}$ [10]. This fact indicates a significant thermodynamic gain in the formation of more stable $\mathrm{Si}_{3} \mathrm{~N}_{4}$. The free energy in the formation of $\mathrm{Si}_{3} \mathrm{~N}_{4}$ directly from $\mathrm{Si}$ and $\mathrm{N}$ atoms is $45 \mathrm{~kJ} / \mathrm{mol}$. 
In our case, due to temperature, partial release of nitrogen atoms occurs, which leads to the formation of a second phase with a high formation energy $-\mathrm{Si}_{3} \mathrm{~N}_{4}$, i.e., the mechanism of structural transformations (transition) from the metastable state of $\mathrm{Si}_{3} \mathrm{~N}_{4}$ to a stable one. The formation of such a stable phase contributes to the retention of a higher relative concentration of $\mathrm{Si}$ atoms in the formed coating and an increase in hardness.

The data obtained indicate that by varying the nitrogen pressure and bias potential applied to the substrate, by selecting the appropriate composition of cathodes and alloying elements, it becomes possible to optimize the coating deposition modes.

\section{CONCLUSIONS}

Silicon alloying of solid solutions of transition metal nitrides determines the formation of composite phases in the coating. The improvement of the physical and mechanical properties of the coatings is observed.

Varying the physical parameters of deposition allows improving the physical and mechanical characteristics of the coatings. The resulting coatings are characterized by superhardness and high modulus of elasticity.

The observed extreme values of mechanical characteristics make it possible to determine close to optimal values of the deposition parameters of ion-plasma coatings.

The results of tribological studies show that the wear resistance of coatings based on the (Ti-Hf-Si)N system is an order of magnitude higher than the wear resistance of coatings based on (Ti-Hf)N. The friction coefficient of (Ti-Hf-Si) N coatings during testing was observed on average $20 \%$ lower than the coefficient of friction of coatings of the (Ti-Hf)N system.

Optimization of the cathode composition and physical parameters of the deposition allows the formation of ion-plasma coatings with programmable properties.

\title{
REFERENCES
}

1. O.M. Ivasishin, A.D. Pogrebnjak, S.N. Bratushka, Nanostructured layers and coating formed by ion-plasma fluxes in titanium alloys and steels, 286 (Kyiv: Akademperiodyka: 2011).

2. V.A. Belous, A.S. Kuprin, S.N. Dub, V.D. Ovcharenko, G.N. Tolmacheva, E.N. Reshetnyak, I.I. Timofeeva, P.M. Litvin, J. Superhard Mater. 35 No 1, 20 (2013).

3. P.J. Martin, A. Bendavid, J.M. Cairney, M. Hoffman, Surf. Coat. Technol. 200 No. 7, 2228 (2005)

4. J.E. Krzanowski, Surf. Coat. Technol. 188-189, 376 (2004).

5. X.D. Zhang, W.J. Meng, W. Wang, L.E. Rehn, P.M. Baldo, R.D. Evans, Surf. Coat. Technol. 177-178, 325 (2001).

6. V.V. Grudnitskiy, V.M. Beresnev, A.A. Drobyshevskaya, P.V. Turbin, I.N. Toryanik, S.S. Grankin, D.A. Kolesnikov, U.S. Nemchenko, Phys. Surf. Eng. 10 No 3, 286 (2012).

7. V.M. Beresnev, O.V. Sobol, A.D. Pogrebnjak, P.V. Turbin, S.V. Lytovchenko, Tech. Phys. 55 No 6, 871 (2010).

8. V.M. Beresnev, S.A. Klimenko, I.N. Toryanik, A.D. Pogrebnjak, O.V. Sobol', P.V. Turbin, S.S. Grankin, J. Superhard Mater. 36 No 1, 29 (2014).

9. R.F. Zhang, A.S. Argon, S. Veprek, Phys. Rev. B 79, 245426 (2009).

10. R.F. Zhang, S. Veprek, Thin Solid Films 516, 2264 (2008).

\section{Еволюція властивостей іонно-плазмових покриттів на основі нітридів тугоплавких металів}

\author{
П.В. Турбін, В.М. Береснев, Д.В. Горох
}

Харківський національний університет ілені В.Н. Каразіна, майдан Свободи, 4, 61022 Харків, Украӥна

Визначаються деякі закономірності формування покриттів на основі нітридів перехідних металів, отриманих вакуумно-дуговим методом. Покриття формувалися із застосуванням ВЧ імпульсної стимуляції підкладинки. 3 метою усунення крапельної фракції застосовувалася сепарація іонноплазмового потоку. Для визначення фізико-механічних властивостей покриттів у роботі використовувалася растрова електронна мікроскопія і метод наноіндентування. Морфологія поверхні покриттів аналізувалася із застосуванням електронно-іонного мікроскопа. Еволюція фізико-механічних властивостей покриттів визначається фізичними параметрами осадження. Склад катодів, що розпорошуються; тиск реакційного газу; потенціал зміщення, який подається на підкладинку, визначають структурно-фазовий стан отриманих покриттів і, тим самим, їх фізико-технічні характеристики. Застосування кремнію як легуючого елемента дозволяе формувати міжкристалітний шар $\mathrm{Si}_{3} \mathrm{~N}_{4}$. Сегрегація аморфної або квазіаморфної речовини в міжкристалітний простір визначає композитну структуру в покритті. Композитні покриття характеризуються досконалішими фрізико-механічними властивостями. Отримані в роботі нанокомпозитні покриття досягають стану надтвердих покриттів (53 ГПа) і високих значень модуля пружності (430 ГПа). При певних умовах формування покриття набувають текстурованого стану. Проаналізована ступінь зміни розмірів областей когерентного розсіювання від умов осадження. Встановлено, що оптимальне управління фрізичними параметрами осадження дозволяе формувати іонно-плазмові захисні покриття з програмованими властивостями.

Ключові слова: Метод вакуумно-дугового осадження, Фізичні параметри формування покриттів, Фізико-технічні властивості покриттів. 